
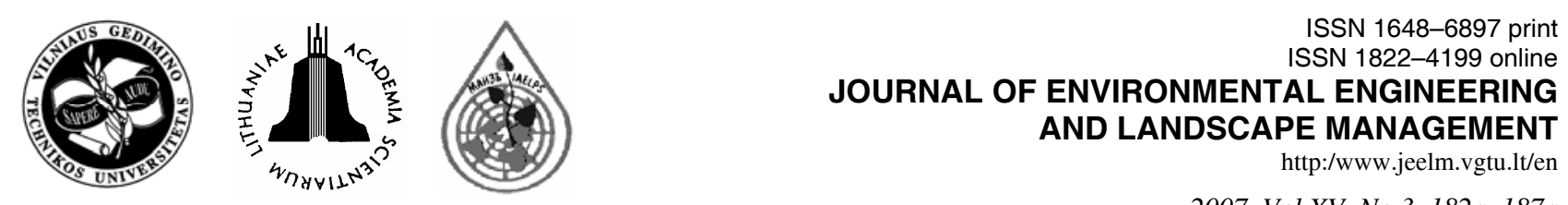

2007, Vol XV, No 3, 182a-187a

\title{
Paper reviene \\ ASPECTS OF WASTEWATER TREATMENT ON SHORT ROTATION PLANTATIONS (SRP) IN POLAND
}

\author{
Agnieszka Karczmarczyk, Józef Mosiej \\ Dept of Environmental Improvement, Warsaw Agricultural University (SGGW), \\ Nowoursynowska 159,02-787 Warsaw, Poland. E-mail: agnieszka_karczmarczyk@sggw.pl
}

Submitted 30 Mar 2006; accepted 11 Apr 2007

\begin{abstract}
The use of wastewater on short rotation plantations (SRP) can be an effective way of wastewater treatment as well as a source of water and nutrients for growing plants. Wastewater nutrient reusing is necessary, especially in the case of nutrients which come from non-renewable resources, as phosphorus. The production of mineral fertilisers is usually a resource-consuming and energy-consuming process. Nutrient removal from wastewater in conventional wastewater treatment technologies is also energy-consuming and expensive. That's why the reuse of nutrients from the waste streams is very important from both economic and environmental point of view. Taking into consideration climatic conditions (annual precipitation, temperature, length of vegetation period), environmental goals (concerning reduction of greenhouse gas emissions, increase of share of renewable energy in total energy production and protection of water resources) and other social and economic aspects, there is a large potential of fast-growing plant species development in Poland. To obtain high and stable energy biomass production, irrigation and fertilisation will be needed, what in simple and low-cost way, can be realised by irrigation with wastewater.
\end{abstract}

Keywords: nutrients reuse, irrigation with wastewater, fast growing plants, renewable energy, water and air pollution

\section{Introduction}

As a result of quite a big area and high population density, Poland is one of the main polluters of the Baltic Sea in the case of nitrogen and phosphorus. The share of waterborne input of nitrogen and phosphorus into the Baltic Sea by HELCOM countries in 2000 amounted $25 \%$ and $37 \%$ respectively [1]. Population of Poland is 38622000 , and from this number almost 15000000 people live in rural areas. About $59 \%$ of population is served by wastewater treatment plants on the scale of the whole country, however, in rural areas this percent amounts only $18,8 \%$ of rural population [2]. Statistical data shows that there is $1625221000 \mathrm{~m}^{3}$ of municipal wastewater treated in 2875 wastewater treatment plants (WWTP) and about $307655836 \mathrm{~m}^{3}$ of wastewater is treated in 35878 on-site and 2031 local wastewater treatment plants [3]. According to unofficial data, it is estimated that the number of on-site WWTP is close to 100000 , serving 400000 people, which is about $3 \%$ of population living in rural areas [4]. About $58 \%$ of waterborne nitrogen and about $50 \%$ of waterborne phosphorus load to the Baltic Sea from the catchment area comes from agriculture and forestry (Fig 1). About $80 \%$ of nitrogen load from rural areas comes from the farmstead, from non-properly stored animal waste and non-properly managed domestic wastewater. Non-treated or nonproperly treated wastewater, together with animal faeces and agricultural soil erosion, are the main source of sur- face water pollution from rural areas. In that way nutrients are getting irretrievable, what on the example of phosphorus is shown in Fig 2. Waste streams of nutrients could be reduced significantly by reclamation, recycling or reuse. Wastewater reclamation, recycling and reuse serve an important function in water resources management by providing a means to produce quality source water for irrigation, industrial and urban water requirements throughout the world [5].

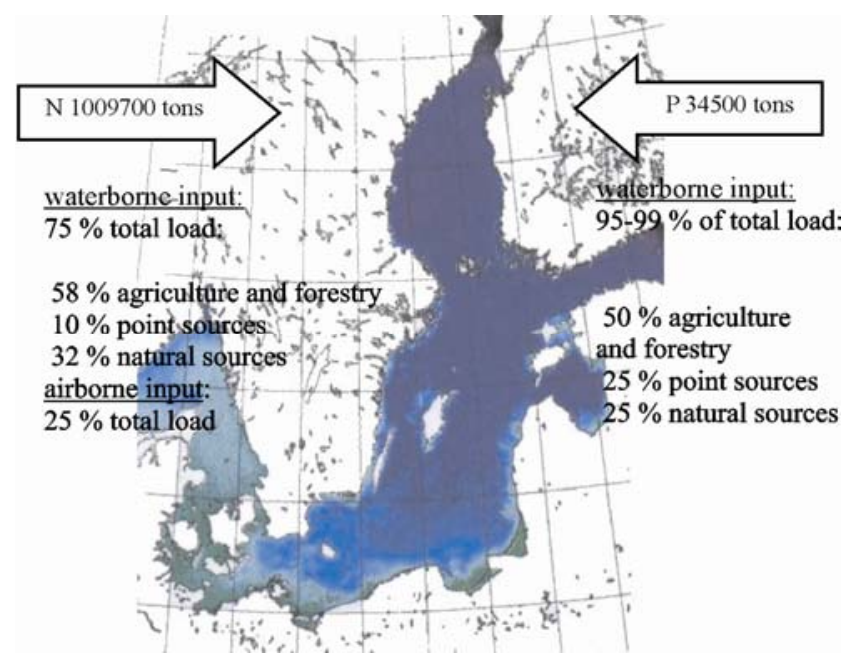

Fig 1. Nitrogen and phosphorus input into the Baltic Sea by HELCOM countries in 2000, according to data from [1] 
The inclusion of planned wastewater reclamation, recycling and reuse in water resource systems reflects increasing societal demands for water, technological advancement, public acceptance and improved understanding of public health risk [6].

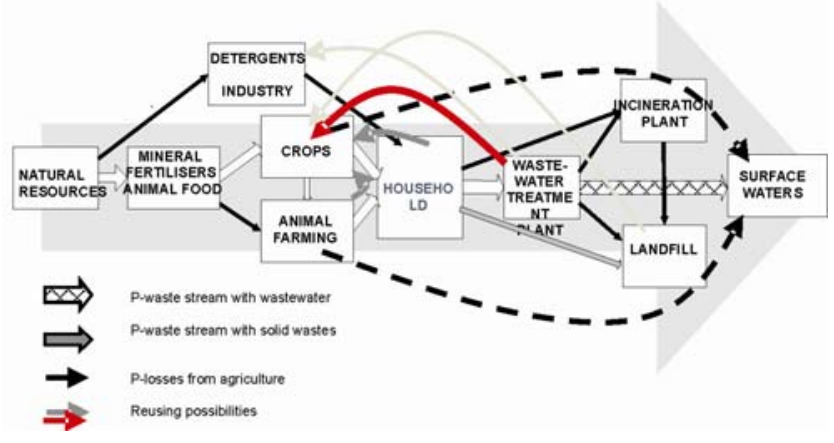

Fig 2. Waste streams of phosphorus and possibilities of reusing

The objective of the work was to point out and discuss the main aspects of wastewater use on short rotation plantations and to show advantages and disadvantages of using SRP as a tertiary step of wastewater treatment in the frame of external and internal legal requirements. Perspectives of wastewater treatment on SRP in Poland has been also discussed.

\section{Aspects of wastewater treatment on short rotation plantations}

Due to principles of sustainable development, solving of environmental problems (water pollution by wastewater) should stimulate solutions to social and economic problems. Environmental, economic and social aspects of wastewater nutrient reuse for production of energy plants will be discussed on the background of external and internal legal aspects of wastewater treatment on SRP (Fig 3).

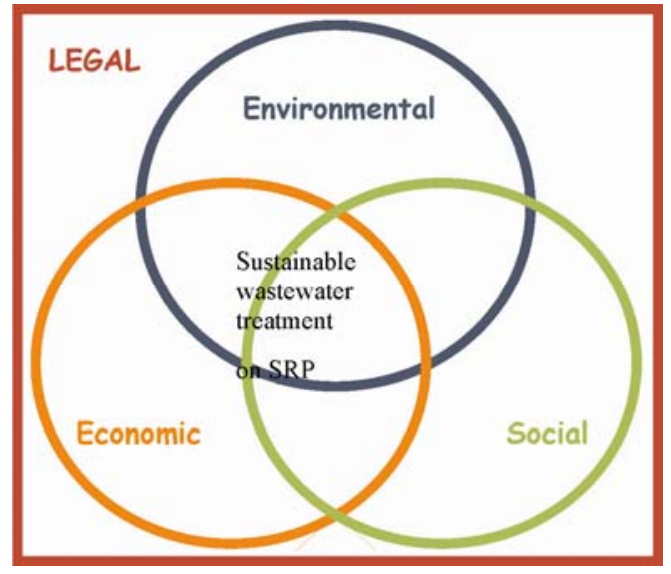

Fig 3. Aspects of wastewater treatment on SRP

\subsection{Legal aspects}

As a member of the European Union, Poland is subjected to external legal requirements. It is expected that the promotion of an integrated approach to water resource management, as it is spelled out in the Water Framework Directive (WFD) [7], will favour municipal wastewater reclamation and reuse to be implemented on a larger scale, for both augmenting water supply and decreasing the impact of human activities on the environment [8]. It was also stated by the Urban Wastewater Treatment Directive (UWWTD) [9] to reuse treated wastewater "whenever appropriate". To obtain significant level of nutrient removal from wastewater, it might be sustainable and cheap just reclaiming the municipal WWTP effluent and reusing it, for example, in agriculture. This would achieve protection of the water quality while reducing the water and fertilizer demand from fresh water resources. On the other hand, according to WFD, rivers must aim to reach good status until 2015. It will not be possible without rapid decreasing of pollutants discharged to rivers with WWTP effluents, even if permitted limits are kept.

From the other site, wastewater reuse on SRP can be also forced by the Kyoto Protocol, EC-White Paper and Europe's Common Agricultural Policy (CAP) [10-12]. Expected reduction of $6 \%$ of greenhouse gas emission until 2008 and target on increasing the share of renewable energy in total energy generation in the EU countries to $12 \%$ in 2010 require an additional annual production of 53 million tons of wood until 2010 (present trend is only 10 million additional tons) $[10,11]$. The Europe's Common Agricultural Policy is shifting towards a development and diversification of economic activities, providing multiple activities and alternative income [12]. Those two goals can be reached by biomass production on short rotation plantations.

Polish development strategy of renewable energy sector [13] assumes increase of renewable energy share in energy production to 7,5\% in 2010 and $14 \%$ in 2020. Within renewable energy sources available in Poland, biomass seems to have the largest potential, estimated to $90 \%$. About $70 \%$ of renewable energy should be obtained from agricultural production of energy plants (SRP). Predicted energy use in present year is approximated to $4000 \mathrm{PJ}$, in which $87 \mathrm{PJ}$ should be produced from energy plants. Making assumption that 1 ha of a short rotation plantation gives about 310 GJ of energy, over 800 thousand ha of SRP is needed to reach the goal of the $7,5 \%$ share of renewable energy sources in energetic balance of Poland in 2010. The natural productivity of willow biomass in Polish climatic conditions is about $14 \mathrm{Mg}$ of dry mass per ha. It can be increased by balanced irrigation and fertilisation with wastewater. According to national legal requirements, wastewater applicable on the land should be pre-treated, to get at least $20 \%$ reduction of organics $\left(\mathrm{BOD}_{5}\right)$ and not less than $50 \%$ reduction of suspended solids. Moreover, Salmonella spec, nematode eggs and toxic substances should be also controlled. Soil used for wastewater irrigation should have a limited content of heavy metals, and wastewater irrigation should be based on nutrient balance. There are also some limitations according to terms of wastewater application. It is prohibited from December to the end of February, and when the soil is frozen, covered by snow or 
ground water table is higher than $1,5 \mathrm{~m}$ below the soil surface. Also soils on the slope higher than $20 \%$ should be avoided [14]. From that point of view, in any case we use wastewater for irrigation, we have to predict a place for storing the wastewater or treat it in a different way during the winter period.

\subsection{Economic aspects}

Treating of wastewater on SRP provides benefits from both the farmer and WWTP point of view. Use of biogens and organics from wastewater instead of mineral fertilizers decreases costs of biomass production. Wastewater is also a low-cost water source for irrigation. Farmers interested in SRP gain from diversification of agricultural production and, what follows, diversification of income sources. It can be calculated that profit from 1 hectare of SRP amounts 170 Euro (estimated cost of biomass production "-_. 235 Euro/ha; subvention "+" 55 Euro/ha; market price of biomass 25 Euro per $\mathrm{Mg}$ d.m.* average biomass productivity $14 \mathrm{Mg}$ d.m./ha = "+" 350 Euro/ha).

Biomass without any elaboration is characterised by a low heating value and large volume (density of 200$250 \mathrm{~kg} \mathrm{~m}^{-3}$ ). To be economically acceptable for a power plant, biomass should be produced at a distance not exceeding $50 \mathrm{~km}$ [15].

Reuse of wastewater on SRP is also profitable for the WWTP operator, as it reduces costs of wastewater treatment (nutrient removal) and layoffs from costs of use the environment. Between 7-20 Euro per kilo of N normally was paid for conventional treatment in 1997. In some cases SRP can be an alternative to conventional treatment and reduce wastewater treatment costs for small communities up to $80 \%$.

\subsection{Social aspects}

Development of energy plant production and service sector results in strengthening rural areas by creating employment, developing local products and, what follows, pushing local economy. Every 20 ha of SRP can generate one new workplace in agriculture. Moreover, energy biomass production promotes the creation of new employments in the whole renewable energy sector, from biomass production, through the processing, and finally in distribution and combustion. It also promotes development of sectors connected to biomass processing, e $\mathrm{g}$ equipment for harvesting, cutting, pellets preparation, furnace for biomass combustion etc. In generally, renewable energy sector can bring from 1,5 to 2 times more workplaces than conventional power plants, 15 times more than nuclear plants, and 5 times more than fossil fuel sector [15]. Moreover, availability of cheep carbon source promotes its use, and opens up new markets for renewable energy consumption.

The other social aspect of wastewater treatment on SRP which should be mentioned, is society opposition towards use of recycled water. However, the latest research shows, that irrigation of forests, trees and other non-food crops is rather acceptable for the society (opposition of 10-11\%) [16]. Low opposition to irrigation with wastewater prognoses wilder use of this water and biogens source in short rotation plantations.

\subsection{Environmental aspects}

Use of biogens from wastewater for SRP fertilization decreases pollution of surface water, because it works as a tertiary step of wastewater treatment. It can also result in improving the quality of surface waters on areas where a high percentage of the population currently has no connection to wastewater treatment facilities. To avoid pollution of the environment, volume and rates of wastewater used for irrigation should be based on nutrient and water balance.

Biomass production based on wastewater fertilization and irrigation results in closing the nutrient loop. Wastewater nutrients back in the form of produced biomass human households and are used for energy production. It results in improvement of biological balance of local ecosystems and decreasing of material flow through the use of local energy sources [15].

Fast growing plants irrigated and fertilized with wastewater are low-cost and on-site available source of biomass for local heating plants and single households, generating a local, renewable and $\mathrm{CO}_{2}$ neutral source of energy. It will result in reduction of a low emission of greenhouse gases to the atmosphere.

\section{Generalisation: State of the art and perspectives of wastewater treatment on SRP in Poland}

The number of SRP and their area in Poland has been growing in the last years. According to the data of the Ministry of Agriculture and Rural Development, about 6 000 ha of agricultural land was covered by Salix $s p$ and Rosa multiphlora var plantations in 2005 (Fig 4). However, a real area covered by plants cultivated for energy purposes is much bigger. There are also significant areas where other plant species, e g Robinia pseudacacia L., Sida hermaphrodita, Helianthus tuberosos L., Reynoutria sachalineris, Reynoutria Japonia, Sylphium perfoliatum, Cynara cardunculus, Miscanthus sinesis, Spartina pectinata, Andropogon gerardi, Populus L., Phalaris arundinacea, are cultivated, but for now, they are not subsidized.

Agricultural production of fast-growing tree species can be realized in a wide variety of climate and soil conditions [17]. While poplars are cultivated especially in dryer areas, willows were found to be the most suitable crop for regions characterized by a short vegetation period and high precipitation rates. Natural conditions, e g precipitation, temperature, solarity and vegetation period, are favourable for development of SRP in Poland. With average vegetation period from 210 days (Gdańsk) to 215 days (Kraków) and precipitation of 500-700 $\mathrm{mm}$ the natural productivity of willow can be as high as $14 \mathrm{Mg} \mathrm{d}$ m per ha.

It is estimated that there is an area of about 3000000 ha of abandoned land in Poland, because of fulfilling a market for traditional agricultural food crops during the last years [18]. However, only about 1000000 ha is characterised by conditions favourable for 
energy plants [19]. According to Kowalik [20] the maximum area which can be covered by energy plants in Poland amounts $1 \%$ of agricultural land.

Natural local conditions, e $g$ the soil productivity, hydrogeology and topography, are favourable in many parts of the Polish agricultural land. But they are not the only factor influencing development of SRP. A very important factor is also the infrastructure. Closeness to a power or heating plant (final biomass destination), development of road infrastructure (transport possibilities) and nearness of WWTP (source of wastewater and sludge) can be the factors influencing the worthfulness and driving forces of SRP development.

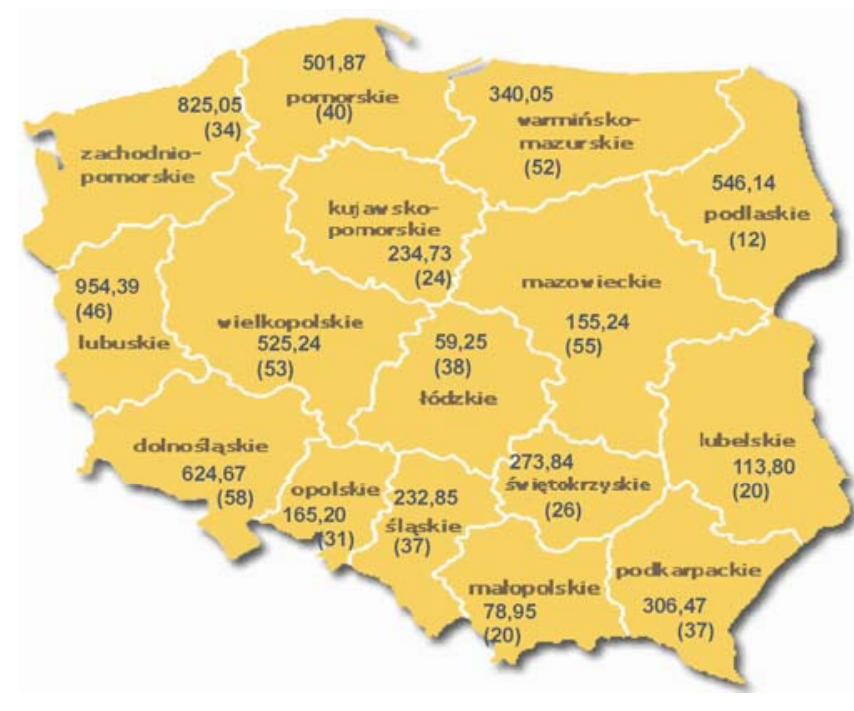

Fig 4. Woiewodships with the largest and lowest Salix plantation area [ha]. Number of plantations shown in brackets according to data from Polish Ministry of Agriculture and Rural Development

To reach the goal of $7,5 \%$ share of renewable energy in total energy generation in 2010, there is a need of about 3 million $\mathrm{Mg}$ of waste wood from forests and 4-5 million $\mathrm{Mg}$ of biomass from SRP. Estimated potential of wind energy is from 1 to $1,5 \%$, hydroelectricity $2-2,5 \%$, and a small amount of geothermal and solar energy [21]. Among the other significant biomass sources for energy production in Poland, straw, hay, wood and sludge for biogass production should be mentioned. Surplus mass of straw in Poland is estimated on 9-12 million $\mathrm{Mg}$ per year (technical potential $195 \mathrm{PJ}$ ). It is the cheapest available fuel. However, installations for combustion of straw are very expensive. Actually, only $1 \%$ of produced straw (25 million $\mathrm{Mg}$ per year) is used as an energy source. Mass of wood available for use as a fuel amounts 8,8 million $\mathrm{Mg}$ per year (technical potential 57,6 PJ). In 2002 in Poland wood biomass was used in both large $(>500 \mathrm{~kW}-180$ installations) and small $(<500 \mathrm{~kW}-110$ thousand installations) heating plants. At the end of 2004 over 2000 wastewater treatment plants were operated, with average flow between 50 and $100000 \mathrm{~m}^{3} \mathrm{~d}^{-1}$. The number of people connected to these plants is over $20 \mathrm{mln}$. Over 360 thousand $\mathrm{Mg}$ of $\mathrm{d} \mathrm{m}$ of sludge is produced yearly. Pre- dicted number of produced sludge in the near future is about 420 thousand $\mathrm{Mg}$ of dry matter. Only 7,5\% of produced sludge reaches the chemical norms for agricultural use. Unfortunately, sludge biogass production is profitable when the volume of treated wastewater is higher than 20 thousand $\mathrm{m}^{3}$ per day.

Effluents from wastewater treatment plants can efficiently be used for irrigation by avoiding direct discharge and providing an additional treatment step. In areas with low access to modern treatment facilities, like dispersed rural regions, SRP can be a low-cost alternative for construction of cost-intensive high-standard treatment technologies. Currently, particularly willows seem to meet the requirements for efficient treatment and utilization of wastewater by irrigation because of their fast growth, high water and nutrient uptake rates and coppice-ability. On the assumption that $15 \mathrm{~m}^{2}$ of SRP will be predicted for wastewater treatment from 1 person (with a daily discharge of 100 litres per person), with a 10 ha SRP during the vegetation period, a biological treatment of wastewater from about 6500 people will be possible.

The application of wastewater on SRP has enormous potential in regions where the treatment performance is currently insufficient or not available, like, for instance, in dispersed rural areas. Taking into account the EU-25 and Candidate Countries connection rate is less than $50 \%$, and the total figure is close to 135000000 citizens from which the wastewater needs to be treated to fulfil existing EU standards. In addition, at least half of existing wastewater treatment plants will have to be modernized to meet legal requirements within 10 years, while decentralized systems will increase their relative importance in the European Market. SRP can be an alternative to other bio filters because of treatment combined with production of wooden biomass process provides additional income.

On the one hand, SRP represent an economic solution for highly efficient biomass production and low-cost wastewater and sludge treatment, on the other hand, they can contribute to the local independency from external fossil fuels and their price fluctuation, to less environmental pollution and more local employment. The main advantages of wastewater use on SRP are:

- efficient wastewater treatment,

- increase of biomass production rate with limited use of mineral fertilizers,

- reuse of nutrients by introducing waste to the biological cycle,

- protection of surface water,

- diversification of agricultural production (agroenergy).

The potential of short rotation plantation development in rural areas of Poland will be forced by diversification of income sources and contribution to the local independence from external fossil fuels. Biomass production combined with wastewater treatment makes this approach a very interesting opportunity for farmers and will further contribute to lowering water and air pollution and a sustainable rural development. 


\section{Acknowledgements}

The presented work was carried out within work packages 1 and 3 of SPB programme (50905270077) founded by the Polish Ministry of Scientific Research and Information Technology and FP6 Craft project WACOSYS.

\section{References}

1. Nutrient pollution to the Baltic Sea in 2000. Helsinki Commission. Baltic Marine Environment Protection Commission, p. 24.

2. Central Statistical Office. Yearbook of Poland 2005.

3. Agriculture. Forestry. Environment. Central Statistical Office 2001.

4. BŁAŻEJEWSKI, R. Aktualny status przydomowych oczyszczalni ścieków i perspektywy ich rozwoju. Wodociagi - Kanalizacja, 2005, No 1, p. 4.

5. ASANO, T.; LEVINE, A. D. Wastewater reuse: a valuable link in water resources management. Water Quality Journal, 1995, No 4, p. 5.

6. ASANO, T.; LEVINE, A. D. Wastewater reclamation, recycling and reuse: past, present, and future. Wat. Sci. Tech., 1996, Vol 33, No 10-11, 1-14.

7. Water Framework Directive 2000/60/EC of the European Parliament and of the Council of 23 October 2000 establishing a framework for Community action in the field of water policy.

8. BIXIO, D.; THOEYE, C.; DE KONING J.; JOKSIMOVIC, D;, SAVIC, D., WINTGENS, T.; MELIN, T. Wastewater reuse in Europe Desalination. 2006, 187, p 89-101.

9. Urban Wastewater Treatment Directive (UWWTD) (91/271/EEC) Council Directive 91/271/EEC of 21 May 1991 concerning urban waste-water treatment.

10. Kyoto Protocol (1997) to the united nations framework convention on climate change, English Conference of the Parties.
11. EC-White Paper 1997 Energy for the Future: Renewable Sources of Energy. White Paper for a Community Strategy and Action Plan COM(97)599, p 55.

12. Europe's Common Agricultural Policy Council Regulation (EC) No 1698/2005 of 20 September 2005 on support for rural development by the European Agricultural Fund for Rural Development (EAFRD).

13. Strategia Rozwoju Energetyki Odnawialnej (realizacja obowiązku wynikającego z Rezolucji Sejmu Rzeczypospolitej Polskiej z dnia 8 lipca 1999 r. w sprawie wzrostu wykorzystania energii ze źródeł odnawialnych). Ministerstwo Środowiska, Warszawa, wrzesień 2000.

14. Rozporządzenie Ministra Środowiska z dnia 8 lipca 2004 r. w sprawie warunków, jakie należy spełnić przy wprowadzaniu ścieków do wód lub do ziemi, oraz w sprawie substancji szczególnie szkodliwych dla środowiska wodnego Dz.U. 2004 nr 168 poz. 1763.

15. MAJCHRZAK, H.; ŚCIAZŻKO, M.; ZUWAŁA, J. Produkcja energii odnawialnej w BOT Elektrownia Opole SA. Stan obecny i perspektywy rozwoju. Energetyka, 2005, Nr 5.

16. DOLNIČAR, S.; SAUNDERS, C. Recycled water for consumer markets - a marketing research review and agenda. Desalination, 2006, 187, p 203-214.

17. STAŃCZYK, K.; TRZĄSKI, L.; BIENIECKI, M.; KADLEWICZ, K.; CARUK, M. Ekologia dla przedsiębiorstw. Cz. 1. Polska Izba Ekologii, 2004, p 25-29.

18. KASPEROWICZ, A Rolnicze surowce energetyczne. Agro Serwis, 2004, No 19-20, p 18-19.

19. DUBAS, J. W. Możliwości i ograniczenia produkcji biomasy wierzbowej $\mathrm{z}$ przeznaczeniem jej na cele energetyczne w: Stan i perspektywy polskiej energetyki odnawialnej - biomasa". MODR Poświętne, 66-73.

20. KOWALIK, P. Biomasa jako odnawialne źródło energii. In: „Stan i perspektywy polskiej energetyki odnawialnej biomasa". MODR Poświętne, 2004, p 35-40.

21. ŚCIAŻ̇KO, M. Biblia ,zielonych” producentów. Gigawat Energia, 2004. 11, p 33-36.

\section{NUOTEKU NAUDOJIMO TRUMPOS ROTACIJOS PLANTACIJOSE LENKIJOJE ASPEKTAI}

\section{A. Karczmarczyk, J. Mosiej}

\section{S antrauka}

Nuotekų naudojimas trumpos rotacijos plantacijose gali būti efektyvus nuotekų tvarkymo būdas, taip pat drègmès šaltinis ir maistinè medžiaga augalams. Nuotekose esančių maistinių medžiagų pakartotinis naudojimas yra būtinas, ypač kai maisto medžiagos gaunamos iš neatsinaujinančių šaltinių, pvz., fosforas. Mineralinių trą̌u gamybai dažnai reikia daug žaliavų ir energijos. Maistingų medžiagų šalinimui iš nuotekų taikant tradicines nuotekų tvarkymo technologijas taip pat reikia daug energijos, ir tai yra brangiai kainuojantis procesas. Todėl nuotekose esančių maistingų medžiagų antrinis panaudojimas yra labai svarbus ekonominiu ir aplinkosauginiu požiūriais. Atsižvelgiant ị klimato būklę (metinis kritulių kiekis, temperatūra, vegetacijos trukmè), aplinkosauginius tikslus (šiltnamio efektą didinančių dujų mažinimas, atsinaujinančios energijos dalies padidinimas bendroje energijos gamyboje ir vandens išteklių apsauga) ir kitus socialinius bei ekonominius aspektus, Lenkijoje yra galimybė didinti greitai augančių augalų rūšių plotus. Norint greitai ir stabiliai išauginti daug biomasès, reikia augalus drèkinti ir tręšti ir tam gali būti naudojamos nuotekos.

Reikšminiai žodžiai: maistinių medžiagų antrinis panaudojimas, drèkinimas nuotekomis, greitai augantys augalai, atsinaujinanti energija, vandens ir oro tarša. 
ВОЗМОЖНОСТИ ИСПОЛЬЗОВАНИЯ СТОЧНЫХ ВОД НА ПЛАНТАЦИЯХ РАСТЕНИЙ КОРОТКОЙ РОТАЦИИ В ПОЛЬШЕ

А. Карчмарчик, Ю. Мосией

Р е 3 ю м е

Использование сточных вод на плантациях растений короткой ротации может быть эффективным средством ухода за сточными водами, а также источником влаги и пищевых продуктов для растений. Вторичное использование пищевых продуктов из сточных вод является обязательным, особенно в тех случаях, когда пищевые продукты получаются из невосстанавливающихся источников, например, фосфор. Производство минеральных удобрений требует многих сырьевых материалов и энергии. Процесс удаления пищевых продуктов из сточных вод с помощью традиционных технологических методов является дорогостоящим и требующим больших энергетических затрат. Поэтому вторичное использование пищевых продуктов из сточных вод важно в экономическом и природоохранном отношении. С учетом климатических условий (годового количества осадков, температуры, срока вегетационного периода), природоохранных целей (уменьшения количества тепловых газов, увеличения доли восстанавливаемой энергии в общем производстве энергии, охраны водных ресурсов), а также других социальных и экономических аспектов в Польше имеется возможность развивать сорта быстрорастущих растений. Для того, чтобы уровень продукции биомассы был высоким и стабильным, необходимо постоянное орошение и подкормка. Для этих целей и могут использоваться сточные воды.

Ключевые слова: вторичное использование пищевых продуктов, орошение сточными водами, быстрорастущие растения, восстанавливаемая энергия, загрязнение воды и воздуха.

Agnieszka KARCZMARCZYK. Doctoral student, Dept of Environmental Improvement, Warsaw Agricultural University (SGGW).

Józef MOSIEJ. Professor, Dept of Environmental Improvement, Warsaw Agricultural University (SGGW). 